\title{
PERANCANGAN MODEL ARSITEKTUR SISTEM INFORMASI KERETA REL LISTRIK MENGGUNAKAN TEKNOLOGI NEAR FIELD COMMUNICATION
}

\author{
Holong Marisi Simalango ${ }^{1}$ \\ Hery Heryanto ${ }^{2}$ \\ Program Studi Teknik Perangkat Lunak, Universitas Universal ${ }^{1}$ \\ Kompleks Maha Vihara Duta Maitreya, Kota Batam \\ Program Studi Sistem Informasi, STMIK LIKMI² \\ Jl. Ir. H. Djuanda No 96, Kota Bandung \\ simalangoholong@gmail.com ${ }^{1}$ \\ h3ry.heryanto@gmail.com ${ }^{2}$
}

\begin{abstract}
ABSTRAK
Perancangan Sistem informasi alternatif lebih berfokus terhadap penggunaan teknologi baru yaitu near field communication (NFC) sebagai alternatif yang difokuskan pada teknologi yang akan digunakan pada transportasi umum khususnya kereta rel listrik (KRL). Object oriented analys (OOA) adalah metodologi yang digunakan dalam perancangan arsitektur SI KRL dan menggunakan Unified Modelling Language (UML). Perancangan arsitektur terdiri dari arsitektur bisnis, arsitektur informasi, dan arsitektur teknologi. Hasil dari perancangan arsitektur SI KRL adalah berupa blueprint dan rekomendasi perancangan untuk pengembangan sistem informasi khususnya di KRL kawasan Jabodetabek.
\end{abstract}

Kata Kunci : near field communication (NFC), Commuter Line (CL), Object Oriented Analys (OOA)

\section{PENDAHULUAN}

Kemajuan teknologi mempengaruhi banyak pada sisi kebutuhan hidup, bahkan seakan menjadi kebutuhan primer. Pemanfaatan teknologi membantu interaksi manusia, keperluan sehari-hari, dan menjadi alat bantu. Kemajuan teknologi dapat dirasakan seperti pada transportasi umum baik moda transportasi darat, laut, dan udara. Pengembangan sistem informasi transportasi yang ada di Indonesia misalnya informasi rute moda trasportasi, dan informasi pembelian tiket online.

Beberapa kota besar di Indonesia (mulai) menerapkan teknologi digital untuk menjadi smart city, baik di bidang e-Government, e-Toll, e-Ticketing untuk Commuter Line untuk kota besar, dan sebagainya. Teknologi e-Toll telah diterapkan untuk kota besar di Indonesia, namun masih menggunakan kartu fisik yang disebut e-Toll Card untuk melewati Gardu Tol Otomatis (GTO). Jakarta, Bogor, Depok, Tangerang dan Bekasi atau yang disingkat dengan Jabodetabek telah dibangunnya pelayanan transportasi umum yaitu commuter line atau yang sering disebut kereta rel listrik (KRL). KRL yang berada di kawasan Jabodetabek dapat mengurangi penggunaan kendaraan pribadi dengan biaya tiket yang sangat murah.

Masyarakat Indonesia adalah negara yang paling cepat mengikuti perkembangan piranti bergerak yaitu smartphone. Beberapa smartphone dari android versi 4 atau Ice Cream Sandwich yang diproduksi dari tahun 2013 telah ditanamkan fitur teknologi Near Field Communication (NFC). NFC yaitu teknologi yang dapat memberikan kemudahan 
untuk konektifitas dan berbagi data. Negara Singapura telah menerapkan teknologi NFC untuk pembelian tiket Mass Rapid Transit (MRT) dengan menggunakan aplikasi EZ-Link yang memiliki fungsi sama dengan e-Toll Card. EZ-Link memiliki fitur lebih yaitu dapat melakukan (auto) top-up, update card, dan active EZ-Load. Pengguna EZ-Link hanya mendekatkan smartphone ke Tag NFC Pasif di gerbang masuk MRT.

Teknologi NFC disebut-sebut sebagai dompet elektronik. Pengembangan teknologi NFC bisa dimanfaatkan sebagai kartu pembayaran elektronik untuk kemudahan menggunakan transportasi umum. Pengembangan teknologi NFC juga dimanfaatkan untuk menyediakan pengunduhan jadwal keberangkatan dan kedatangan, serta jalur transportasi umum khususnya KRL di kawasan Jabodetabek.

Pertumbuhan penduduk Indonesia yang sangat tinggi dan kondisi-kondisi sekarang yang masih banyak menggunakan tiket kertas atau kartu KRL fisik yang memiliki resiko sengaja ataupun tidak sengaja seperti retak dan luntur. Permasalahan ini dapat diselesaikan dengan menggunakan kemajuan teknologi NFC. Pengembangan teknologi ini dapat mengurangi penggunaan kartu fisik, kertas, tenaga dan waktu dari sistem yang sedang berjalan. Pengembangan teknologi NFC adalah sistem informasi alternatif yang dapat membantu pelayanan menggunakan KRL di kawasan Jabodetabek, mengurangi antrian, dan mewujudkan smart city. Perancangan sistem informasi alternatif ini bisa dijadikan sebagai model panduan untuk penerapan teknologi NFC di Indonesia.

\section{PENELITIAN SEBELUMNYA}

Latar belakang yang mendasari penelitian ini didasarkan dari peneliti sebelumnya Surya Michrandi Nasution (2012) yang berjudul "Prototype of train ticketing application using Near Field Communication (NFC) technology on Android device" yang memaparkan salah satu tujuan dalam menggunakan NFC dalam kehidupan sehari-hari dapat diimplementasikan dalam aplikasi transportasi umum khususnya kereta api. Beliau memberi gambaran prototipe aplikasi untuk pembelian tiket kereta aplikasi untuk piranti bergerak bersistem operasi Android 2.3.3 yang terintegrasi dengan teknologi NFC. Tampilan antarmuka didesain untuk penumpang dan konduktor.

Penelitian lainnya yang mendasari adalah Khan Amjad, dkk (2015) yang berjudul "Prototype of Bus Ticketing Application Using NFC on Android Device" memaparkan tentang tiket dan identifikasi penumpang dalam pelayanan transportasi umum khususnya tiket bis. Penelitian ini diusulkan bertujuan mengembangkan sistem tiket otomatis. Sistem ini bertujuan mengurangi tarif penumpang sesuai dengan jarak yang ditempuh serta mendeteksi identitas penumpang dengan penerapan teknologi NFC

\section{SISTEM INFORMASI ALTERNATIF}

Perancangan sistem informasi alternatif ini merupakan sistem informasi baru dari pengembangan sistem lama yang ada, dimana masalah-masalah yang terjadi pada sistem lama diharapkan sudah teratasi pada sistem yang baru. Sistem informasi alternatif lebih berfokus terhadap penggunaan teknologi baru yang sedang dikembangkan atau dipercayakan sangat bermanfaat untuk masa depan. Teknologi baru banyak telah diciptakan dari beberapa tahun sebelumnya, namun belum maksimal dikembangkan untuk dijadikan alat bantu dalam kehidupan sehari-hari.

Sistem informasi alternatif kereta rel listrik (SI KRL) ini dirancang dari ketersediaan teknologi baru yang sedang ramai dikembangkan yaitu teknologi NFC. Teknologi tersebut telah ditanamkan ke beberapa smartphone dari android versi 4 atau Ice Cream Sandwich yang diproduksi dari tahun 2013. SI KRL dikombinasikan dengan teknologi tersebut. SI KRL ini memberikan pelayanan dan kemudahan bagi para pengguna dan karyawan yang bekerja di kereta rel listrik. Sistem yang memberi informasi jalur, serta jadwal 
keberangkatan dan kedatangan melalui mobile (smartphone) dari pengguna. Sistem tersebut juga mengantikan proses yang sedang berjalan yaitu pada pembelian tiket secara tiket fisik menjadi pengotomatisan menggunakan smartphone dan tag NFC pasif.

\section{PERMASALAHAN UMUM SISTEM KRL}

KRL merupakan salah satu transportasi darat yang merupakan salah satu kebutuhan yang tidak lepas dari di masyarakat disemua kelas baik itu bawah, menengah, dan atas. Penelitian ini mengambil fokus pada KRL di kawasan Jabodetabek. Di kawasan Jabodetabek dengan jaringan KRL yang rumit, (calon) penumpang sering tidak tahu bagaimana cara untuk mencapai daerah tujuan mereka atau merencakan perjalanan ke tujuan lainnya, kecuali tempat yang pernah disinggahi. Misalkan seorang (calon) penumpang akan berpergian dari stasiun Depok Lama ke Serpong, maka penumpang mempunyai pilihan jalur alternatif KRL yang disediakan. Penumpang dapat memilih jenis kartu yang disediakan oleh petugas KRL yaitu kartu harian berjamin (KHB) atau kartu multi trip (KMT). Penumpang dapat melakukan transaksi dengan cara manual atau dengan top up pada mesin tiket berbentuk mesin ATM dengan memasukkan nominal uang tertentu.

Kartu tiket yang sedang digunakan penumpang KRL bahwa telah didapati mengalami kerusakan seperti patah, luntur, dan hilang. Penumpang sering mengeluhkan antrian panjang untuk melakukan top up ke mesin tiket. Kartu tiket yang telah berulangulang digunakan dan mengalami kerusakaan akan susah dideteksi di mesin tag NFC pasif, sehingga memperlambat untuk memasuki KRL. Hal ini juga masih sering terjadi pada penumpang lainnya di stasiun kawasan Jabodetabek.

\section{ANALISIS PERBANDINGAN SISTEM SAAT INI DENGAN SISTEM YANG DIUSULKAN}

Pada sistem yang sedang berjalan terutama pada KRL di kawasan Jabodetabek dijalankan dengan menggunakan kartu fisik. Dengan kondisi kartu fisik sudah tentu memiliki resiko tinggi apabila kartu patah, luntur, dan paling buruknya hilang. Untuk meningkatkan proses layanan KRL dan proses transaksi pembelian tiket, maka pada sistem baru yang akan dirancang memiliki kemudahan baik untuk petugas KRL, dan pengguna layanan ini.

Masyarakat Indonesia yang kian mengikuti perkembangan smartphone, tidak salahnya jika penerapan teknologi NFC dapat menjadi solusi utama mengganti permasalahan layanan KRL. Beberapa manfaat yang bisa diambil dengan adanya perancangan arsitektur SI KRL ini, antara lain :

a. Tersedianya informasi pengunduhan jadwal keberangkatan dan kedatangan, serta jalur KRL.

b. Mengurangi penggunaan kartu fisik, kertas, tenaga dan waktu.

c. Pengisian saldo atau (auto) top up dimana dan kapan saja tanpa harus ke loket tertentu.

d. Hanya bermodalkan smartphone sebagai otentikasi data pribadi bisa menggunakan KRL.

e. Ukuran ongkos yang sesuai dengan jarak perjalanan.

\section{USE CASE BISNIS YANG DIUSULKAN}

Klasifikasi aktor terdiri dari dua jenis, antara lain :

a. Aktor sebagai manusia. Aktor yang berperan dalam proses bisnis dan/atau yang berinteraksi dengan sistem. Aktor tersebut terdiri dari customer dan petugas KRL. 
b. Aktor sebagai piranti. Aktor yang bukan manusia, akan tetapi memiliki peran dalam sistem dan bisnis yaitu mesin tag NFC pasif.

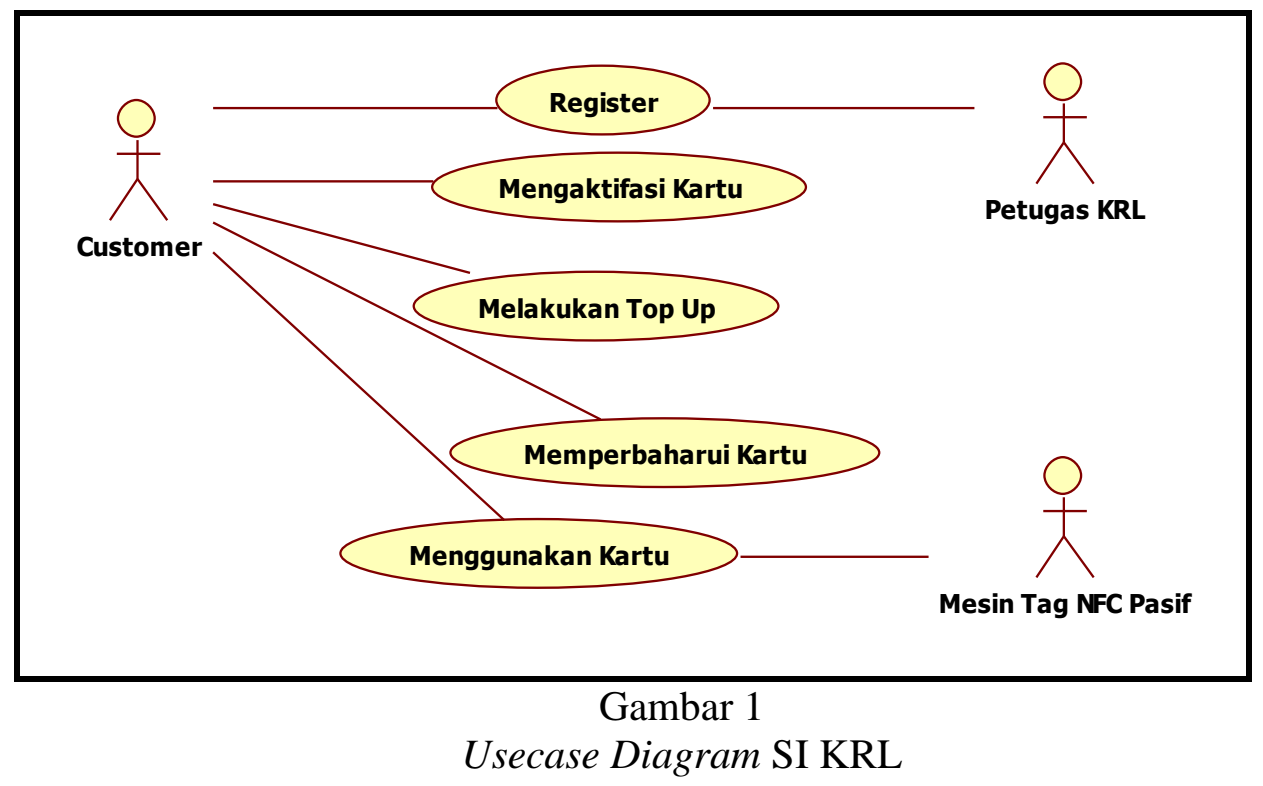

Defenisi aktor, antara lain :

a. Petugas KRL. Aktor yang berinteraksi dengan sistem yakni melakukan register data pengguna kartu KRL.

b. Customer. Customer yang dimaksud adalah pengguna KRL. Aktor yang berinteraksi dengan sistem yakni melakukan register secara langsung pada mobile, melakukan top up, dan menggunakan kartu.

c. Mesin tag NFC pasif. Aktor sebagai piranti dalam proses menggunakan kartu.

Defenisi usecase, antara lain :

a. Register, merupakan proses untuk registrasi data pengguna kartu KRL. Proses ini dapat dilakukan oleh petugas KRL dan customer.

b. Mengaktifasi kartu, merupakan proses untuk mengaktifkan kartu yang dalam jangka waktu tertentu tidak digunakan.

c. Melakukan top up, merupakan proses untuk menambahkan saldo pada sistem kartu

d. Memperbaharui kartu, merupakan proses untuk memperbaharui kartu baik itu dari kartu lama karena masa aktif habis atau kehilangan kartu.

e. Menggunakan kartu, merupakan proses untuk menggunakan mobile sebagai kartu yang telah ditanamkan NFC.

\section{ARSITEKTUR YANG DIUSULKAN}

Arsitektur yang akan dibangun disesuaikan dengan kebutuhan non fungsional. Arsitektur ini digambarkan keterhubungan dari user atau customer ke server. Customer menggunakan mobile sebagai pengganti kartu KRL dengan menempelkan pada mesin tag pasif. Mesin tag pasif terhubung dengan Ethernet ke server, namun melewati firewall sebagai pengontrol akses terhadap jaringan ke server dari pihak luar. Costumer melakukan register tidak jauh beda dengan Ethernet yang digunakan mesin tag pasif, dimana akan melewati firewall untuk terkoneksi dengan server. 


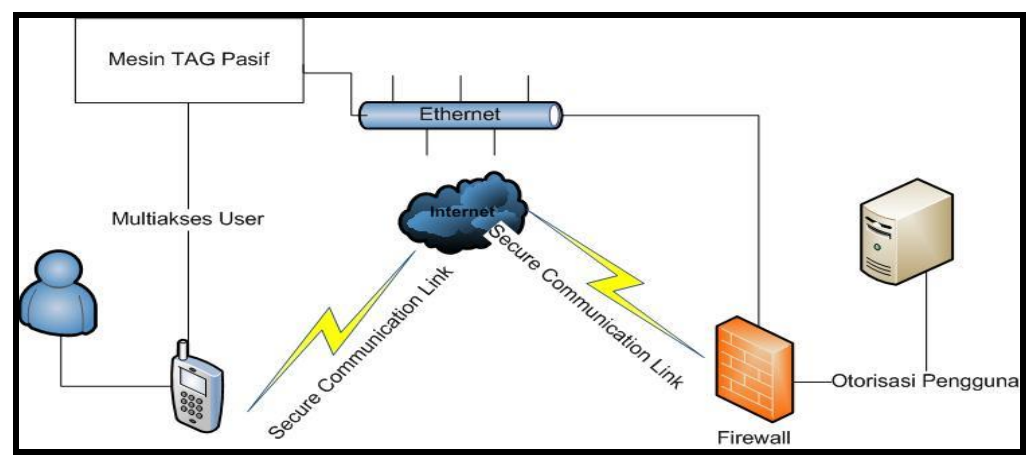

Gambar 2

Arsitektur yang Diusulkan

\section{TOPOLOGI JARINGAN}

Koneksi dari client ke server meggunakan jaringan komunikasi yang dihubungkan dengan Internet dan lokal. Costumer untuk melakukan register akan mengakses server melalui internet. Mesin tag pasif diletakkan di tiap pintu masuk gerbang KRL, sehingga digambarkan dalam jaringan lokal yang terhubung menggunakan switch. Bandwith yang digunakan berkisar lebih besar atau sama dengan 2MBps pada akses server via lokal. Kecepatan bandwith tersebut sangat berpengaruh demi kelancaran dalam penggunaan kartu dalam bentuk mobile. Selain koneksi jaringan lokal dan client pada costumer, jaringan komunikasi data.

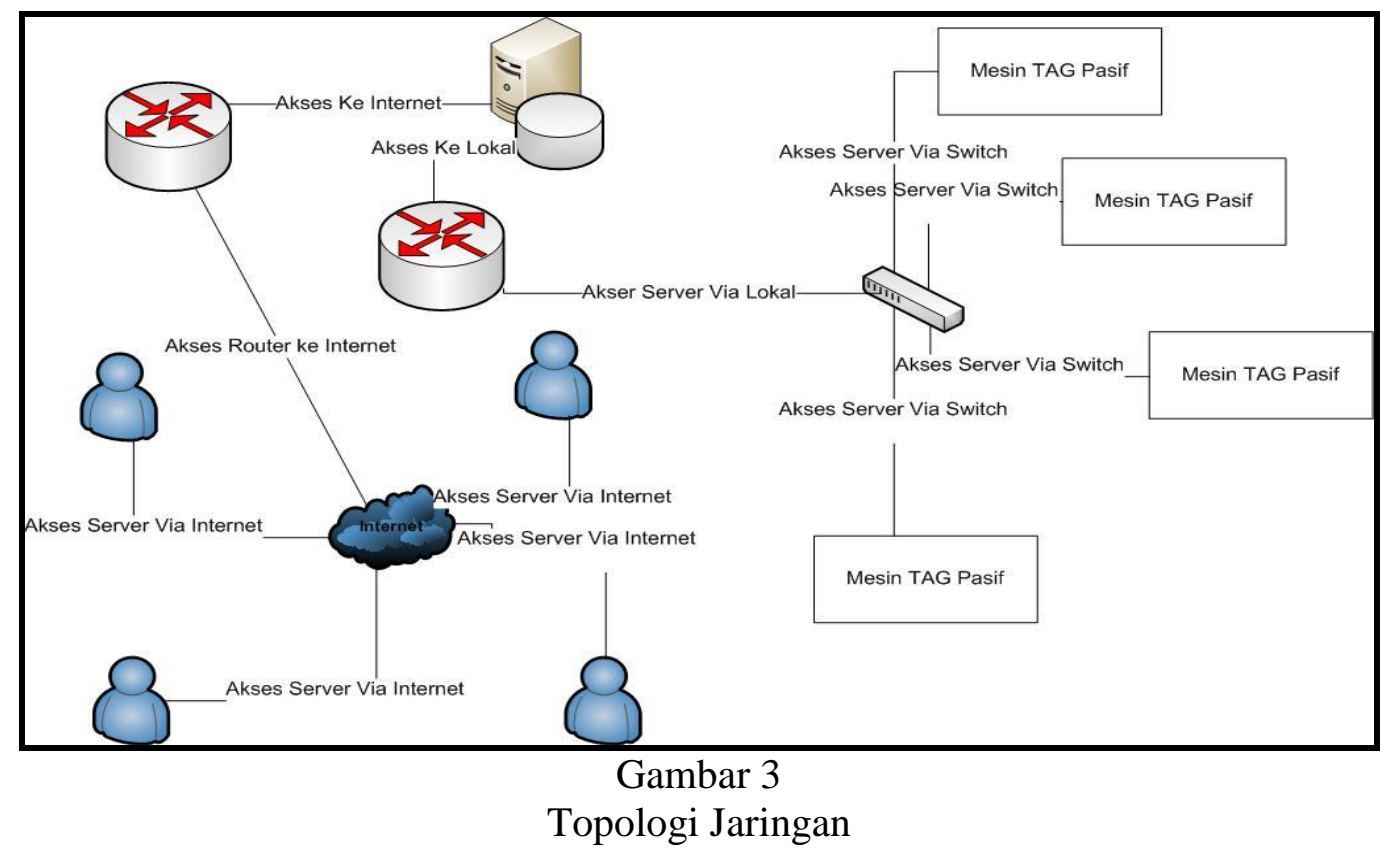




\section{ACTIVITY DIAGRAM YANG DIUSULKAN}

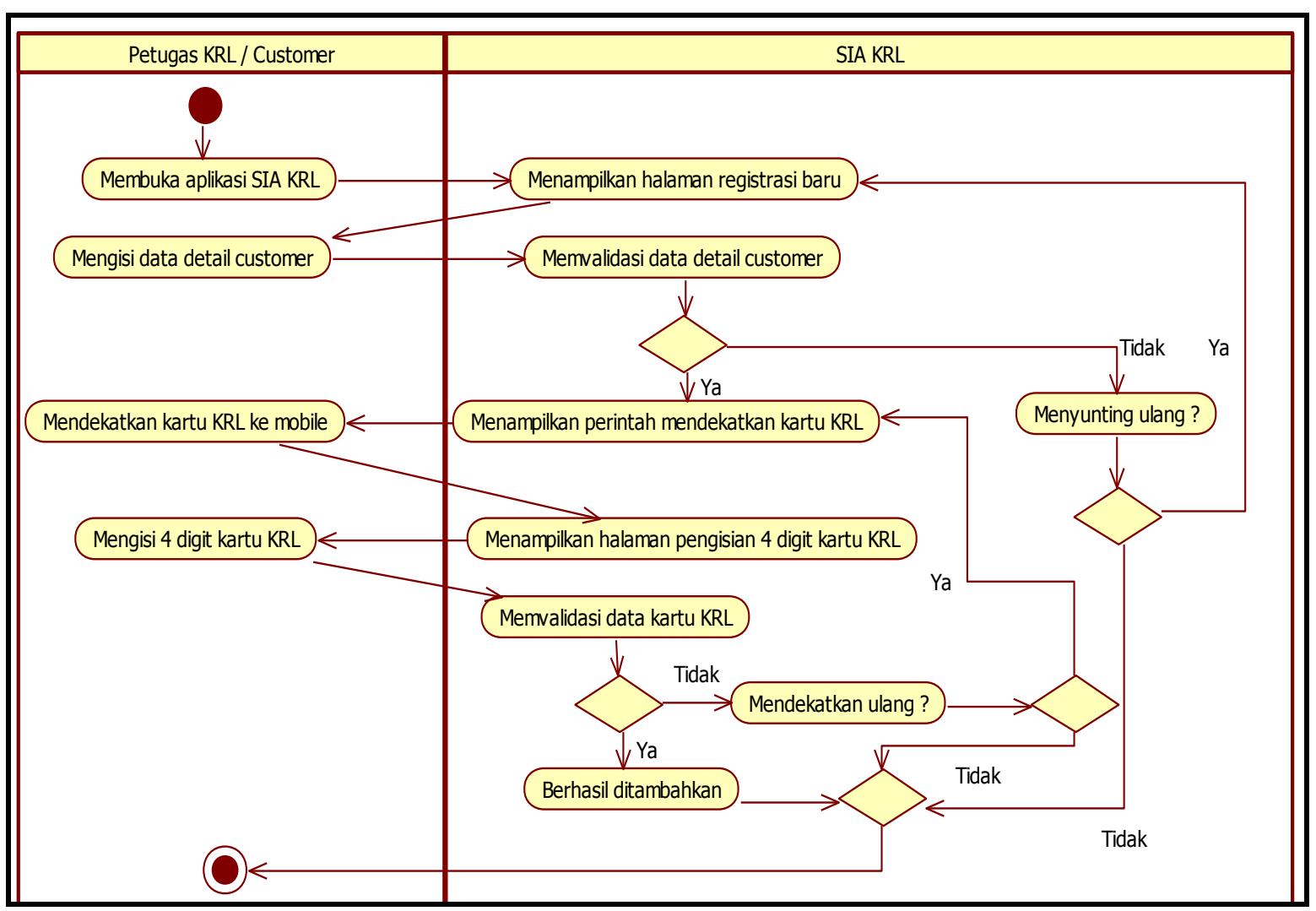

Gambar 4

Activity Diagram untuk Register

Pada gambar 4 menggambarkan bahwa sebelum menggunakan aplikasi SI KRL, terlebih dahulu register data detail customer oleh petugas KRL atau dengan customer. Validasi terdiri dari dua, yaitu :

a. Jika valid, aplikasi akan menampilkan pesan perintah mendekatkan kartu KRL ke mobile dari customer. Aplikasi secara otomatis menampilkan halaman pengisian empat digit kartu KRL untuk konfirmasi. Validasi terdiri dari dua, yaitu :

1) Jika valid, register data ditail customer berhasil didaftarkan.

2) Jika tidak valid, Aplikasi menampilkan pesan pertanyaan untuk mendekatkan ulang kartu KRL atau menutup aplikasi

b. Jika tidak valid, aplikasi menampilkan halaman registrasi baru 


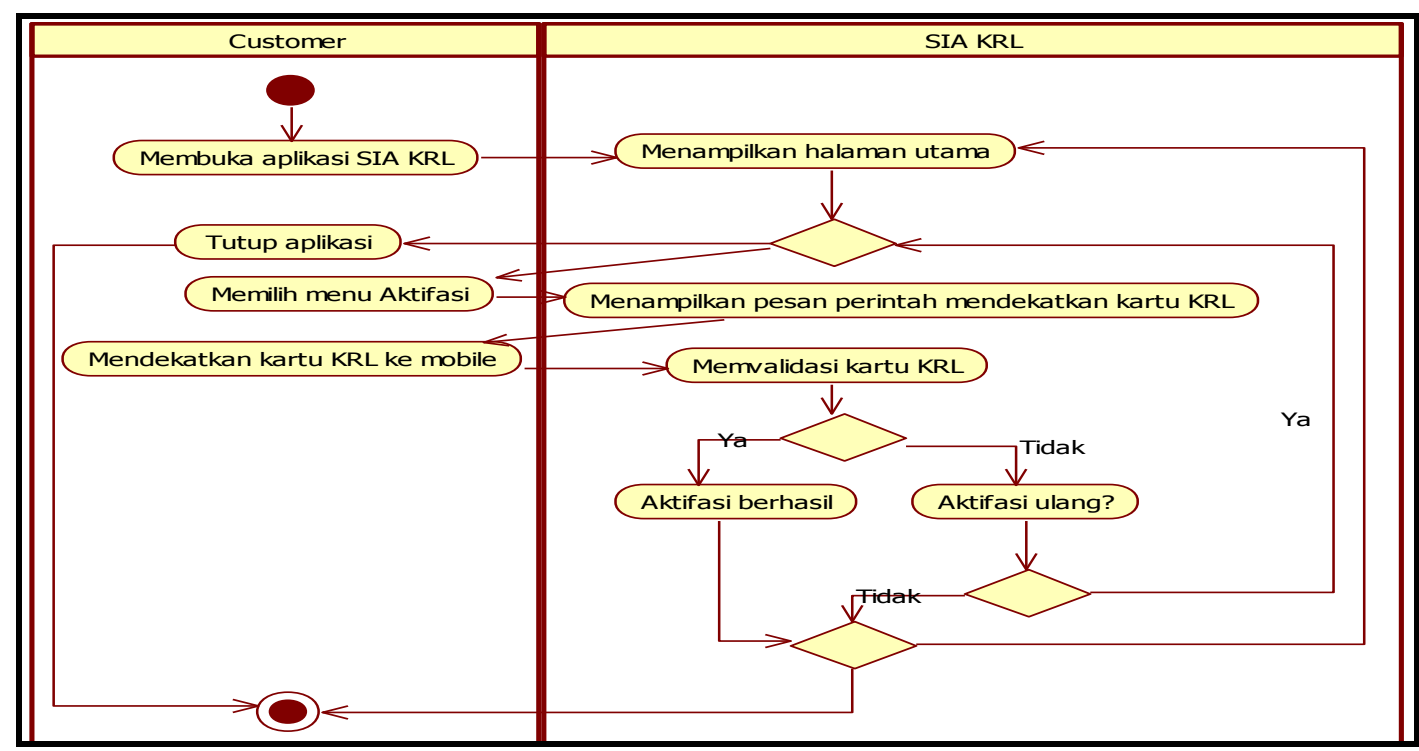

Gambar 5

Activuty Diagram untuk Mengaktifasi kartu

Pada gambar 5 menggambarkan bahwa customer harus membuka aplikasi SI KRL. Aplikasi menampilkan beberapa pilihan menu, customer memilih untuk mengaktifasi kartu. Aplikasi menampilkan pesan perintah untuk mendekatkan kartu KRL terhadap mobile. Aplikasi memvalidasi kartu KRL, validasi terdiri dari dua, yaitu :

a. Jika valid, aplikasi menampilkan pesan aktifasi berhasil.

b. Jika tidak valid, aplikasi memberi pilihan untuk aktifasi ulang atau menutup aplikasi.

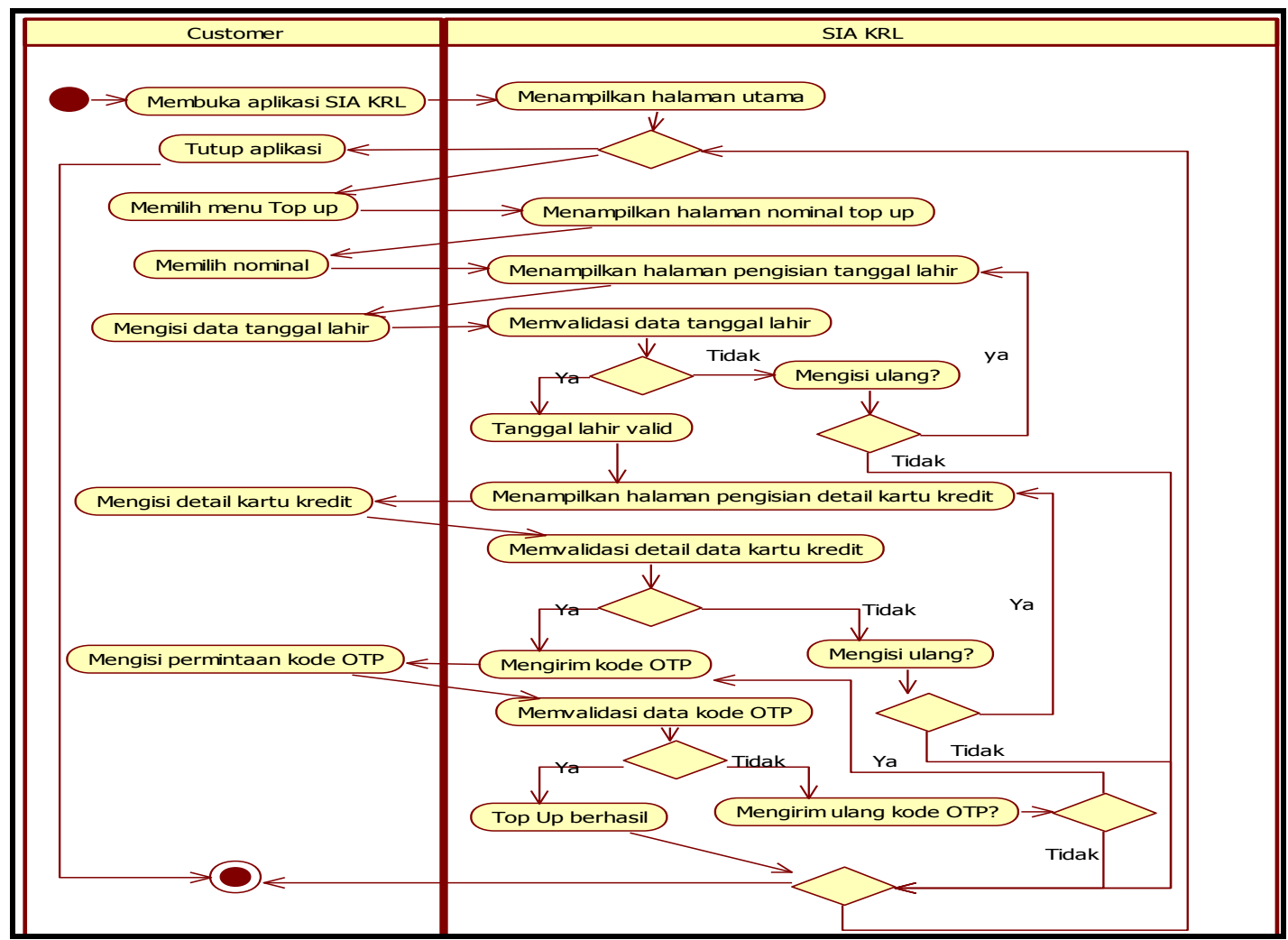

Gambar 6

Activity diagram untuk Melakukan Top Up 
Pada gambar 6 menggambarkan bahwa customer harus membuka aplikasi SI KRL sebelum melakukan top up. Aplikasi menampilkan halaman memilih nominal top up. Aplikasi menampilkan pesan mengisi tanggal lahir sebagai ototentikasi. Aplikasi terdapat dua validasi, yaitu :

a. Jika valid, aplikasi akan menampilkan ke halaman pengisian detail kartu kredit, kemudian dilanjutkan mengirim kode OTP sebagai konfirmasi.

b. Jika tidak valid, aplikasi member pilihan untuk mengisi ulang tanggal lahir atau menutup aplikasi

\section{CLASS DIAGRAM}

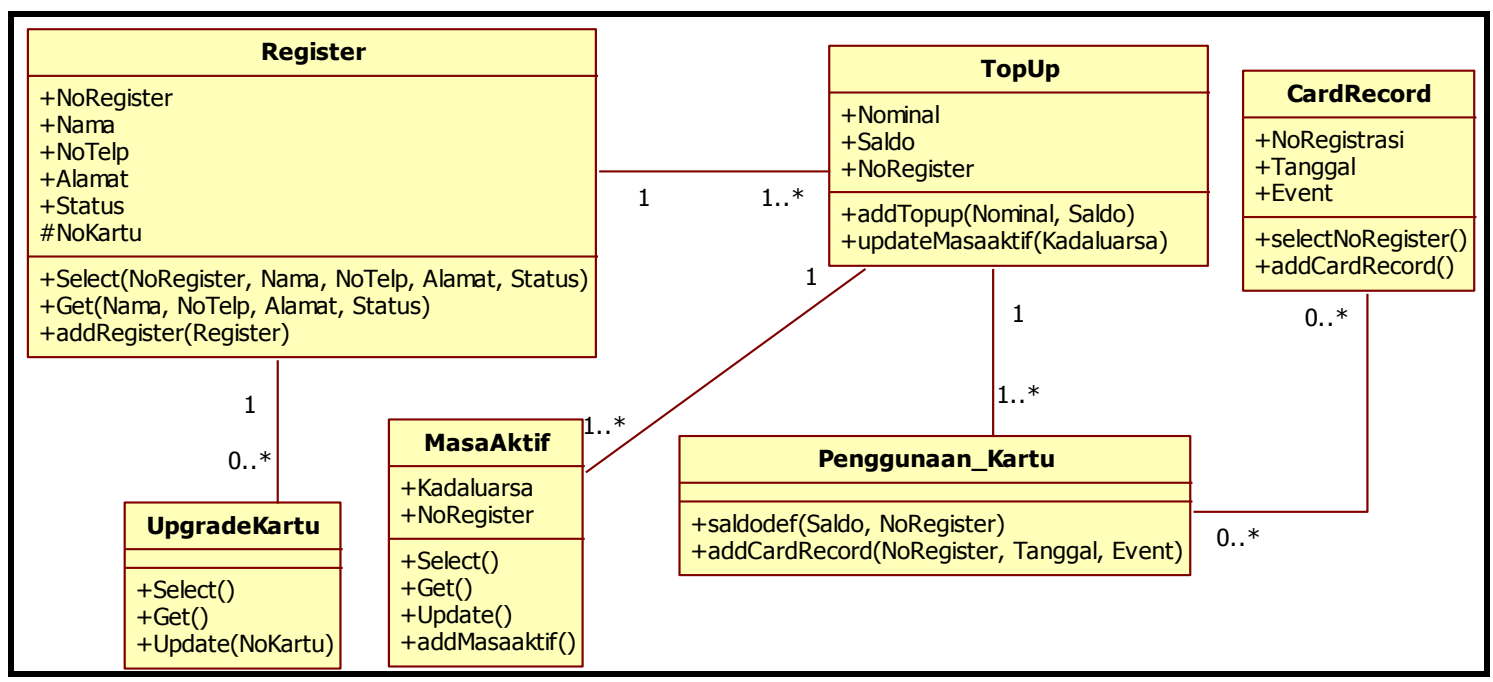

Gambar 7

Class Diagram SI KRL

Gambar 7 menunjukkan keterkaitan hubungan antar kelas yang terdapat pada perancangan sistem informasi alternatif KRL. Kelas Register berfungsi menyimpan datadata register penumpang KRL, Kelas TopUp berfungsi menyimpan data nominal pengisian saldo yang berinteraksi dengan kelas masa aktif, Kelas Penggunaan kartu berfungsi sebagai memangil data dari kelas TopUp dan menyimpannya ke dalam kelas CardRecord.

\section{RANCANGAN ANTARMUKA}

\section{A. RANCANGAN ANTARMUKA REGISTER}

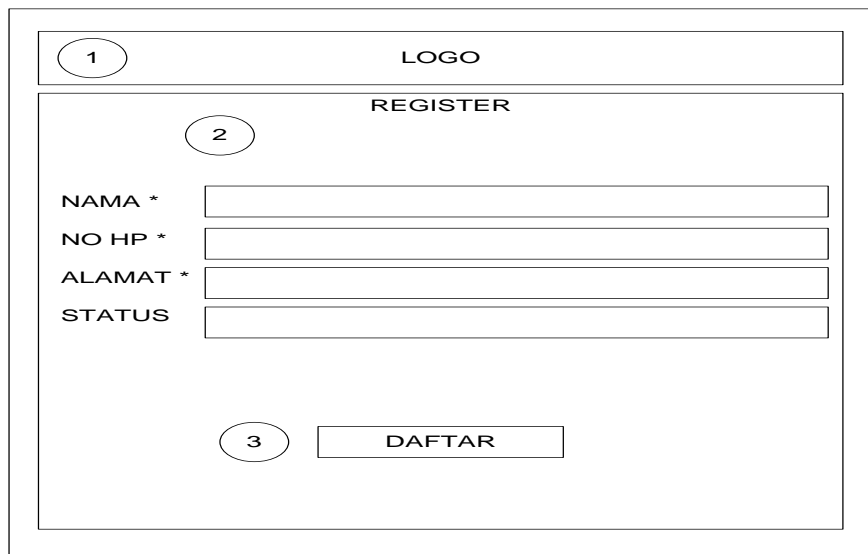

Gambar 8

Rancangan Antar Muka Register 
Keterangan Gambar 8 :

1. Berbentuk gambar tentang logo SI KRL

2. Rangka yang berisi detail kebutuhan untuk register data baru. Penamaan yang ditanda '*' merupakan data yang wajib diisi.

3. Tombol 'DAFTAR' untuk mendaftarkan data customer baru.

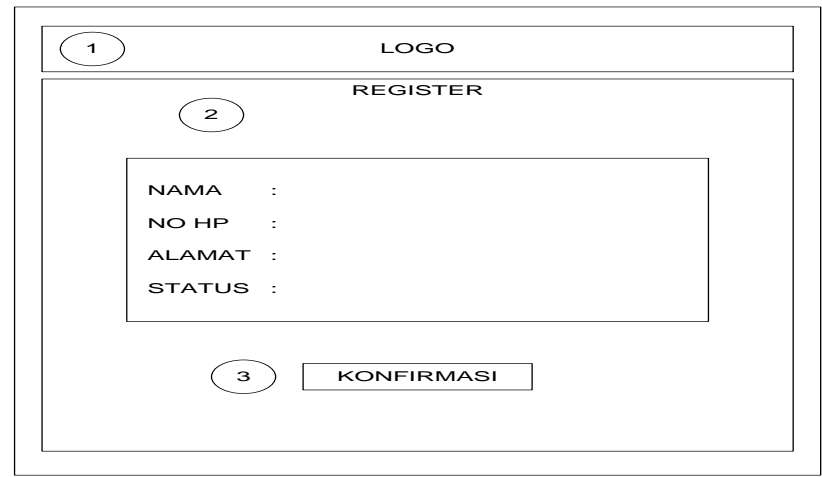

Gambar 9

Rancangan Antar Muka Konfirmasi register

Keterangan Gambar 9 :

1. Berbentuk gambar tentang logo SI KRL

2. Rangka yang hanya menampilkan data registrasi sesuai yang diisi

3. Tombol 'KONFIRMASI' untuk melanjutkan proses selanjutnya.

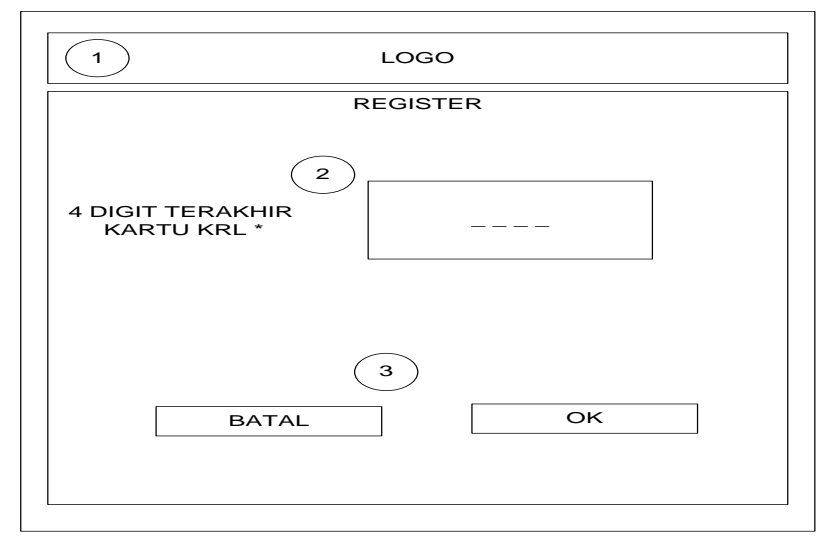

Gambar 10

Rancangan Antar Muka Memasukkan Digit Kartu

Keterangan Gambar 10 :

1. Berbentuk gambar tentang logo SI KRL

2. Rangka register untuk mengisi digit empat angka pada kartu KRL

3. Tombol 'BATAL' untuk membatalkan registrasi. Tombol 'OK' untuk menyelesaikan registrasi. Setelah registrasi sukses, aplikasi akan menampilkan halaman utama. 
B. RANCANGAN ANTARMUKA HALAMAN UTAMA

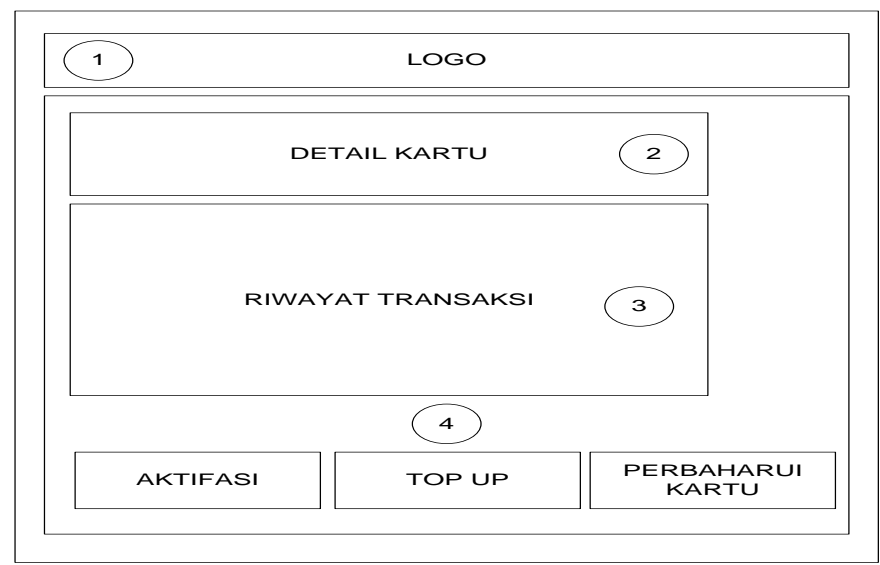

Gambar 11

Rancangan Antar Muka Halaman Utama

Keterangan Gambar 11 :

1. Berbentuk gambar tentang logo SI KRL

2. Rangka yang menampilkan detail kartu KRL

3. Rangka yang menampilkan riwayat transaksi

4. Tombol menu yang terdiri dari 'AKTIFASI', 'TOP UP', dan 'PERBAHARUI KARTU'.

\section{RANCANGAN ANTARMUKA AKTIFASI KARTU}

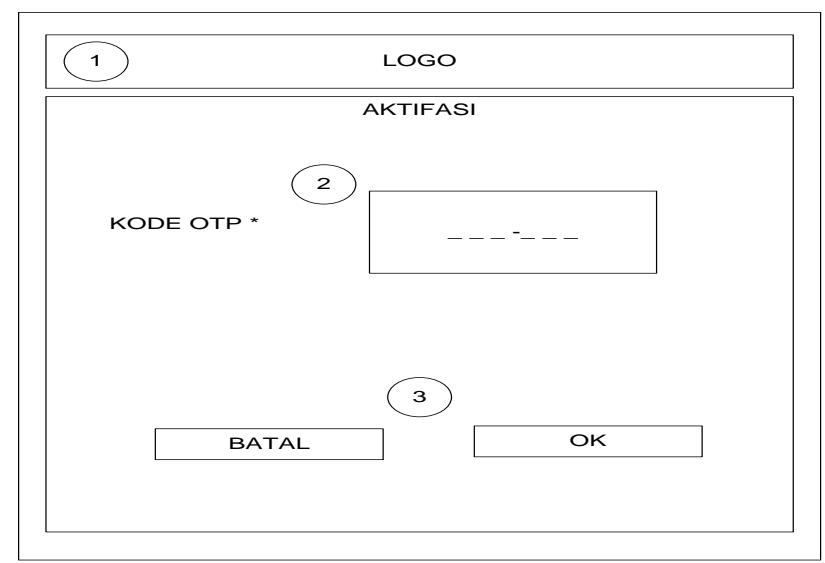

Gambar 12

Rancangan Antar Muka Aktifasi Kartu

Keterangan Gambar 12 :

1. Berbentuk gambar tentang logo SI KRL

2. Rangka untuk pengisian kode OTP

3. Tombol 'BATAL' untuk membatalkan aktifasi kartu. Tombol 'OK' untuk melanjutkan aktifasi kartu. 


\section{RANCANGAN ANTARMUKA MELAKUKAN TOP-UP}

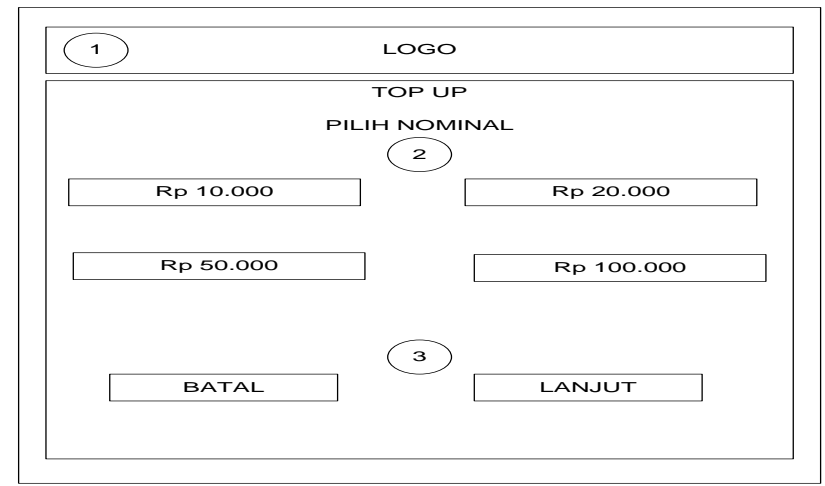

Gambar 13

Rancangan Antar Muka Pilihan Nominal

Keterangan Gambar 13 :

1. Berbentuk gambar tentang logo SI KRL

2. Rangka untuk pilihan nominal top up. Pilihan berbentuk tombol.

3. Tombol 'BATAL' untuk membatalkan top up. Tombol 'LANJUT' untuk melanjutkan proses top up

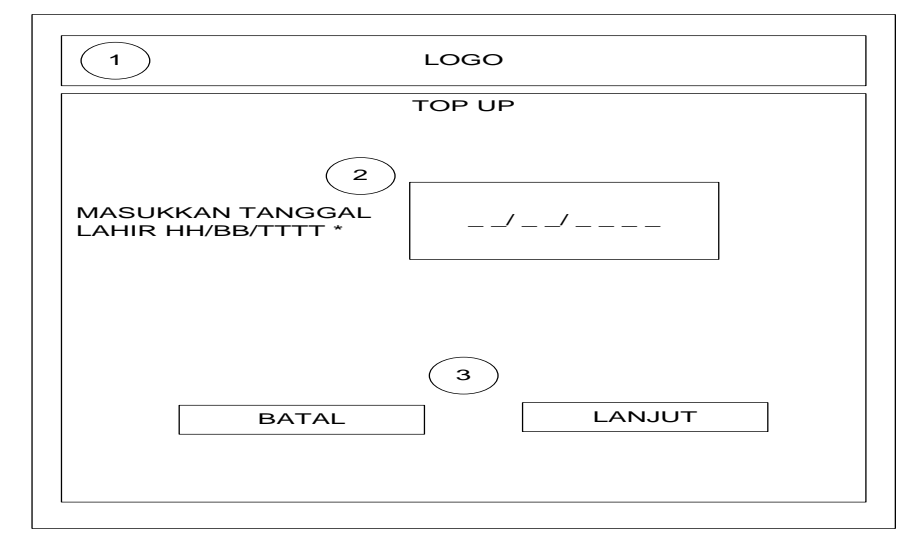

Gambar 14

Rancangan Antar Muka Memasukan Tanggal Lahir

Keterangan Gambar 14 :

1. Berbentuk gambar tentang logo SI KRL

2. Rangka untuk pengisian tanggal lahir pemilik kartu

3. Tombol 'BATAL' untuk membatalkan proses top up. Tombol 'LANJUT' untuk melanjutkan proses top up. 


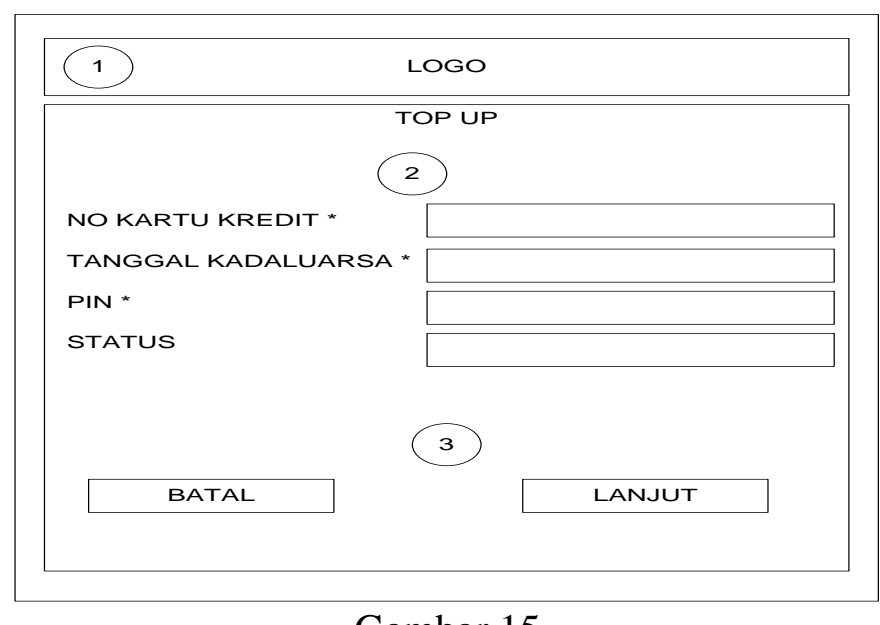

Gambar 15

Rancangan Antar Muka Pengisian Ditail Kartu Kredit

Keterangan Gambar 15 :

1. Berbentuk gambar tentang logo SI KRL

2. Rangka pengisian detail kartu kredit. Penamaan tanda '*' merupakan yang wajib diisi.

3. Tombol 'BATAL' untuk membatalkan proses top up. Tombol 'LANJUT' untuk melanjutkan proses top up

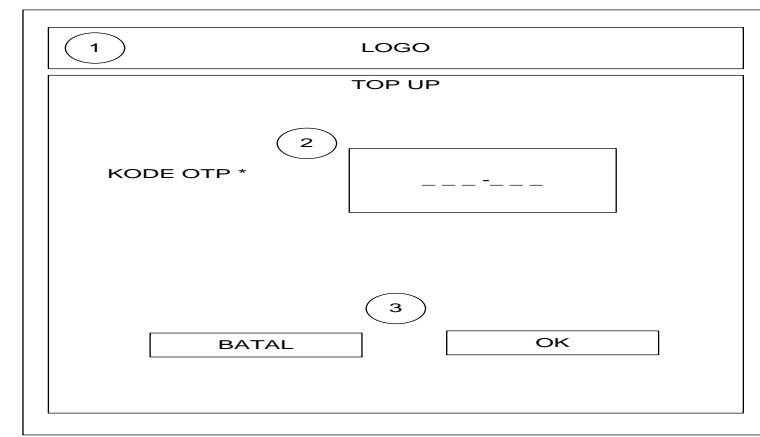

Gambar 16

Rancangan Antar Muka Pengisian Kode OTP

Keterangan Gambar 16 :

1. Berbentuk gambar tentang logo SI KRL

2. Rangka pengisian kode OTP untuk proses terakhir dari top up.

3. Tombol 'BATAL' untuk membatalkan proses top up. Tombol 'OK' untuk menyelesaikan proses top up.

\section{KESIMPULAN}

Perancangan arsitektur SI KRL akan memberikan alternatif kemudahan dan dukungan pada petugas KRL dalam memberikan informasi dan permasalahan yang sedang atau masih dalam proses penanganan perbaikan, dan pada pengguna KRL dalam menggunakan mobile sebagai pengganti kartu KRL.

Perancangan arsitektur SI KRL dapat dijadikan sebagai acuan untuk standarisasi model sistem dengan menggunakan teknologi NFC ini adalah sebagai panduan dalam pengembangan sistem berbasis teknologi NFC di masa yang akan datang khususnya 
pembayaran di transportasi umum untuk KRL di kawasan Jabodetabek. Proses perancangan arsitektur sistem informasi dapat dilakukan dengan terlebih dahulu menganalisis proses bisnis, fungsi-fungsi bisnis, dan pemasalahan yang dimiliki oleh suatu organisasi atau enterprise. Langkah selanjutnya yaitu dengan merancang arsitektur informasi dan arsitektur teknologi.

\section{DAFTAR PUSTAKA}

[1] Amjad, Khan, et all. 2015. Prototype of Bus Ticketing Application Using NFC on Android Device. MHSSCOE.

[2] Anggadini, Sri. 2012. Analisis Sistem Informasi Manajemen Berbasis Komputer Dalam Proses Pengambilan Keputusan. Universitas Padjajaran Bandung.

[3] Ariani, Rosa dan M. Shalahuddin. 2011. Modul Pembelajaran Rekayasa. Perangkat Lunak (Terstruktur dan Berorientasi Objek).Modula.

[4] Bala, Kiran, et all. 2015. A Study on Smartphone based Operating System. Chandigarh University.

[5] Dennis, Allan, et all. 2012. System Analysis and Design : Fifth Edition. John Willey.

[6] Devendran, A.,et all. 2012. Mobile Healthcare System using NFC Technology. Tamil Nadu.

[7] Du, Hongwei. 2013. NFC Technology: Today and Tomorrow. California State University.

[8] Eniyati, Sri. 2006. Pengembangan Berorientasi Objek Metode Fusion. Universitas Stikubank Semarang

[9] Gharehchopogh, Farhad, et all. 2013. Review and Evaluation of Performance Measures in the Mobile Operating Systems. Islamic Azad University.

[10] Hall, James A. 2007. Sistem Informasi Akuntansi. Salemba Empat.

[11] Haviluddin. 2011. Memahami Penggunaan UML (Unified Modelling Language). Universitas Mulawarman.

[12] Kung, David C. 2014. Object-Oriented Software Engineering (An Agile Unified Methodoly). McGraw-Hill.

[13] McLeod, Raymond dan George P. 2008. Sistem Informasi Manajemen : Edisi Indonesia. Salemba Empat.

[14] Safaat, Nazruddin. 2011. Pemograman Aplikasi Mobile Smartphone dan Tablet PC berbasis Android. Informatika

[15] Noh, Sun-Kuk, et all. 2014. Proposed M-Payment System Using Near-Field Communication and Based on WSN-Enabled Location-Based Services for MCommerce. Chosun University.

[16] Setiadi, Bambang. 2008. Pengembangan Arsitektur Sistem Informasi Helpdesk Untuk Menunjang Knowledge Management Pada Divisi Teknologi Informasi PT Bank Jabar. STMIK LIKMI (Unpublised)

[17] Subhan, M. 2012. Analisa Perancangan Sistem. Lentera Ilmu Cendekia.

[18] Sutabri, Tata. 2012. Konsep Sistem Informasi. Andi.

[19] Tantra, Rudy. 2012. Manajemen Proyek Sistem Informasi. Andi Offset.

[20] Tasneem, Sabahat dan Akmal Rehan. 2015. An Evolutionary Testing Solution of Rational Unified Process Model to Develop ERP Software in Pakistan. University of Agriculture Pakistan.

[21] Yakub. 2012. Pengantar Sistem Informasi. Graha Ilmu

[22] Whitten, Jeffery. 2006. Metode Desain dan Analisis Sistem. Andi Offset

[23] http://www.krl.co.id/thb-dan-kmt.html. Diakses tanggal 16 Juni 2016. Jam 07.00 WIB

[24] http://www.dephub.go.id. Diakses tanggal 08 Juni 2016, jam 03.12 WIB. 